\title{
Return Volatility and Macroeconomic Factors: A Com parison of US and Pakistani Firms
}

\begin{abstract}
Sharif Ullah Jan ${ }^{1}$, Hashim Khan ${ }^{2}$, Faisal Khan ${ }^{3}$
Abstract

This study explores the effect of selected economic factors on stock return volatility along with asymmetry and leverage effects on comparative basis of the New York Stock Exchange (NYSE) and Pakistan Stock Exchange (PSX). These dimensions are further investigated with respect to size and age of the firms. The daily stock returns of all the firms on both NYSE and PSX and macroeconomic factors are considered for the period 2000-2015. The results from GARCH $(1,1)$ revealed that all the economic factors have proven their significance in determining the stock returns volatility in both the markets with respect to firm's size and age. More precisely, a negative relationship is observed for market returns (MR), exchange rate (EXR), and oil returns (OIL) with stock return volatility for majority of the firms in both stock markets. Furthermore, risk-free rate (RFR) showed positive and negative effect on the stock return volatility of majority of the firms in NYSE and PSX markets respectively. However, with respect to size and age effects, firms in both the markets exhibited entirely different behavior for all the macroeconomic factors. Further, using EGARCH model, an evidence of asymmetry and leverage effect (with negative coefficient) is found in NYSE and partial evidence (both negative and positive coefficients) in PSX is observed. Again, these results vary with respect to firms' features in both the markets. Therefore, the results of the current study clearly show that there are significant differences in both markets and the investors can diversify their investments and shape their liquidity positions in both markets in order to exploit the maximum benefits from the market and firms specific factors.
\end{abstract}

Keywords: Volatility, leverage, EGARCH, exchange rate

\section{Introduction}

The connection between economic factors and the stock markets is naturally

1 PhD Scholar, Department of Business Administration, Iqra National University, Peshawar.

Email: sharifjan@ciitwah.edu.pk

2 Assistant Professor, Department of Management Sciences, COMSATS Institute of Information Technology, Islamabad

3 Assistant Professor, Department of Finance and Accounting, City University College of Ajman, Ajman, UAE

ARTICLE HISTORY
\begin{tabular}{lll}
$5 \mathrm{Mar}, 18$ & Submission Received & 31 Mar, 18 First Review \\
\hline 4 Apr, 18 & Revised Version Received & 29 Apr, 18 Second Review \\
\hline 8 May, 18 & Revised Version Received & 20 May, 18 Accepted
\end{tabular}


appealing given the role of these markets in stabilizing the financial sector to foster the economic growth of a country (White \& Mala, 2006; Singh, 2010). The CAPM, the "Arbitrage Pricing Theory" and the "Dividend Discount Model" also offer important theoretical frameworks which are further followed by various researchers in both developed and emerging economies (Arestis, Demetriades, \& Luintel, 2001; Chinzara, 2011; Khan, Anuar, Choo, \& Bokhari, 2014a). Moreover, Bhowmik (2013) concluded that the behavior of stock markets is uncertain and highly depends on the behavior of economic fundamentals. The stock return volatility is an important issue to understand by various players in stock markets as it not only affects the efficient allocation of funds but also can hamper the economic development (Arestis et al., 2001). In general, volatility is a drastic fluctuation in value of a financial instrument in a small period of time, e.g. day or week (Okpara, 2011). Similarly, according to Chen, Du, Li, and Ouyang (2013), volatility is the uncertainty to a security that can be calculated using the standard deviation of regular changes in the value of that security. The problem arises when this fluctuation becomes severe and affects the efficiency of stock markets and ends up with stock market crashes (Goudarzi \& Ramanarayanan, 2010). Similarly, Bhowmik (2013) concluded that a very high degree of stock market volatility brings insecurity in the capital market; undermines the value of the currency and hinders international trade and finance; therefore, there is a negative relationship between the economic growth and stock market volatility.

The importance of volatility is also signified through the four important reasons identified by Kearney and Daly (1998); such as, the investors might find it difficult to admit that the causes of these changes prevail in information about fundamental economic variables when their stock prices fluctuate sharply over the short period. This in result eliminates the confidence of investor in the stock market and also becomes the reason for capital flight from the market. Second, from the firm's perspective, volatility is considered as the significant factor for measuring the probability of bankruptcy. Third, volatility also affects the liquidity of the market; as the higher the volatility, the more will be the spread between bids and ask prices for a particular financial instrument. Fourth, volatility also affects the hedging techniques such as insurance policies. For a high level of volatility, the insurance policy price will also be high. Therefore, Kearney and Daly (1998) concluded that high level of volatility discourages the participation of economic agents in the markets which in turn affects the investment levels.

The subsequent sub-sections of introduction endorse the empirical evidence and motivations for all the dimensions along with the embedded relevant literature review.

\subsection{Em pirical relationshi $p$ between macroeconomic factors and stock}




\section{return volatility}

The pertinent financial literature on the relationship between macroeconomic factors and stock return volatility is not very mature and symmetric around both developed and emerging markets (Mamtha $\&$ Srinivasan, 2016). Moreover, the focus of these studies is mainly on how the volatility in macroeconomic fundamentals affects the volatility of stock returns at aggregate market levels using various volatility models (Khan, Khan, \& Khan, 2016). For instance, according to Christie (1982), stock volatility has a significant positive relationship with financial leverage and interest rates. In a similar vein, Schwert (1989) concluded that stock market volatility is affected by various macroeconomic fundamentals and this effect is more prominent in the periods of recession. Applying the APT model, Koutoulas and Kryzanowski (1996) explored the explanatory role of some macroeconomic factors in determining the stock return volatility of the listed firms in Canada. The impact of trading volume of NYSE on stock return volatility was determined by Lamoureux and Lastrapes (1990) and reported a significant relationship between these two. Taiwan industrial firms were examined for the relation between stock return volatility and macroeconomic variables which were divided into real and financial components by Chiang and Doong (2001). Their results revealed that excess returns depend on the macroeconomic factors and the real output volatility is the most significant among others to predict the excess returns. GARCH $(1,1)$ model was applied on data of Singapore Stock Exchange to investigate the impact of interest rate, industrial production (IPI), GDP, inflation, and market return on stock return volatility by Liow (2004). He concluded a significant effect of these variables on stock return volatility of real property stocks. Hammoudeh, Yuan, Chiang, and Nandha (2010) examined the US market for the variations in sector-specific variables i.e. trading volume and price/book ratio along with macroeconomic factors e.g. federal fund rate, world stock returns and oil prices on stock return volatility. Using $\operatorname{GARCH}(1,1)$ model, they found a negative relationship between oil prices and stock return volatility. Ramanathan and Gopalakrishan (2013) reported several macroeconomic factors e.g. inflation, supply and demand, economic growth and uncertainty of company's future. Rajput, Kakkar, Batra, and Gupta (2012) defined volatility as the difference between stock's current prices from its average past prices and hence, all the macroeconomic variables which affect stock returns also affect the stock return volatility. Impact of oil prices, oil price shock and volatility on US stock market returns and volatility have been investigated by Angelidis, Degiannakis, and Filis (2015) and concluded a significant impact of oil price returns and volatility on US stock return and volatility. Similarly, Kang, Ratti, and Yoon (2015) examined the impact of oil prices on the US stock returns and volatility and concluded that oil supply disruption was related to the positive impact on the covariance of return and volatility. 


\subsection{Evidence from emerging markets}

Researchers were not very keen to investigate the emerging markets before 1990's as markets were not fully established; the trading volumes were very low, and the firm's specific information was not always timely and of standard (see Bekaert \& Harvey, 1997). They explored the behavior of volatility in a group of 20 emerging markets (including Pakistan) and tried to achieve three objectives; first, to characterize volatility in emerging economies and presented a number of volatility models. Second, they also explored the determinants of stock return volatility and found a number of worlds and local factors that explained volatility in these emerging markets. And lastly, they examined the forces that cause the difference in volatility among various emerging economies. However, Bilson, Brailsford, and Hooper (2001) argued by applying the principal components approach that emerging stock markets are least partially segmented from global capital markets. Thus, local factors are more important than global factors in determining the market stock returns. This further encourages investors in getting benefits from diversification through allocation of funds across various regions. Indian stock markets are highly subtle and responsive to any change in the expectations about the fundamentals (Agarwal et al., 2010; Singh, 2010). Singh (2010) investigated the impact of macroeconomic variables on the stock returns of Indian equity market and observed a bilateral relation between IPI and equity prices, whereas, concluded a unilateral relation from inflation to market price.

The impact of macroeconomic volatility on the stock return volatility of Malaysian market has been inspected by Zakaria and Shamsuddin (2012). From "bivariate VAR Granger causality", they derived that only inflation and interest rates were significant in Granger causing the stock market returns. Similarly, the regression model revealed that only money supply volatility is significantly explaining the stock return volatility. Nairobi Securities Exchange (NSE) was examined by Kirui, Wawire, and Onono (2014) for the relationship of stock market return volatility and the impact of macroeconomic variables. By applying Engle-Granger and TGARCH models, they reported a negative impact of exchange rate on the stock return volatility while other variables have demonstrated the insignificant impact. Moreover, the leverage effect in NSE i.e. the negative shocks had a greater effect on the volatility than the positives shocks. Oluseyi (2015) conducted his study in the context of Nigeria to examine the relationship between stock return volatility and macroeconomic volatility. Using monthly data of IPI, inflation, money supply, and exchange rate for determining the stock return volatility, they reported exchange rate and inflation as significantly Granger cause the stock return volatility. Further, the results from $\operatorname{GARCH}(1,1)$ showed that exchange rate, interest rate, and money supply affected the stock return volatility in Nigerian markets. 
Similarly, Giri and Pooja (2017) conducted their study in the Indian context and applied "ARDL bounds testing approach to co-integration" to examine the long-run relation, VECM to test the short and long run causality and "variance decomposition" to determine the long run exogenous shocks of them. They reported a long-run relation between the variables. More specifically, a positive impact of economic growth, inflation and exchange rate was found on stock price variations. On the other hand, a negative impact was observed by crude oil price on the stock prices. Bangladesh stock market was explored by Hasan and Zaman (2017) for the likely relationship between macroeconomic variables and return volatility of stocks listed at Dhaka Stocks Exchange (DSE). Their analysis revealed that exchange rate has a positive impact and Bombay Stock Market has a negative impact on the stock return volatility of DSE. A significant effect of exchange rate and interest rate is also concluded by Ali and Shahid (2017) using GARCH-M model for the banking sector of Pakistan.

\subsection{Motivations for asymmetry and leverage effect}

It is believed that in capital markets, positive and negative news regarding financial assets affects volatility of stock returns differently. More precisely, volatility is affected more by negative shocks than positive shocks; this is called the asymmetry and leverage response to volatility. Black (1976) examined the leverage effect on volatility and reported a significant but inverse correlation between stock price variations and volatility response. Subsequently, Chritie (1982), Cheung and Ng (1992), and Mandimika and Chinzara (2012) also investigated the developed market of US for the asymmetry and leverage effects. The asymmetric volatility itself is based on three independent theories i.e. "time-varying risk premia", "asymmetric volatility of economic factors" and both "leverage" and "volatility feedback effect" simultaneously (Mandimika \& Chinzara, 2012).

In a more recent study, the firm level volatility was also highlighted by Sharma, Narayan, and Zheng (2014), who concluded that the firm level volatility is expected to increase over the years more than the aggregate market volatility. Similarly, the study conducted by Mangani (2008) investigated asymmetry and leverage effect apart from the risk and return relationship in capital markets of South Africa. He used EGARCH model but found very little evidence of "asymmetry \& leverage effect" in that market. Sim and Zhou (2015) conducted their study on US stocks and investigated the oil price quantiles impact on the US stock return quantiles. They concluded that large and negative oil price shocks can affect the US stocks favorably when the US stock returns are high. In another study in the context of US, Salisu and Oloko (2015) reported a positive bi-directional shock spillover between the two variables. Furthermore, they

4 See the studies such as Schwert (1989), French and Sichel (1993), Engle and Patton (2001), and Karmakar (2007) among others. 
also found asymmetric shock impact in both markets i.e. why the volatility spillover from oil to stock becomes noticeable after the break which coincides with the period of global economic slowdown.

In the context of PSX, the studies with respect to asymmetry \& leverage effect, particularly at the firm level, are very limited until recently. The existing literature investigated the volatility behavior only at the aggregate level in Pakistan. For instance, Hameed and Ashraf (2006) examined Pakistani firms using GARCH model for the period 1998-2006; GARCH $(1,1)$ and $\operatorname{EGARCH}(1,1)$ was applied on the data for 1997-2004 by Saleem (2007). Zafar, Urooj, and Durrani (2008) applied GARCH (1, 1) model on data set from 2002-2006. Mahmud and Mirza (2011) tested EGARCH model on the data from 2004 to 2009 i.e. before and after the financial crisis. They concluded that the EGARCH model has the capability to capture the asymmetric behavior of stock return volatility in Pakistani market. Qayyum and Anwar (2011) applied EGARCH models and found that there is a significant impact of monetary policy on stock market volatility. Mushtaq, Shah, Rehman, and Murtaza (2011) tested EGARCH model and concluded a direct relationship of inflation and FDI with the stock market and an indirect relation of the exchange rate and interest rate with stock market volatility. Moreover, they also argued that the Pakistani stock markets are comparatively less efficient than the US and other developed markets of the world. Similarly, Arshad, Rani, and Shaikh (2012) found GARCH $(1,1)$ and EGARCH as the best-fitted models to capture the volatility and asymmetric volatility in the Pakistani context. Ali and Afzal (2012) functioned EGARCH model on the data of KSE-100 and BSE-100 and found the negative shocks were having more pronounced impacts on the volatility than the positive shocks. Moreover, both of the stock markets are facing persistent volatility clustering. They all documented that the aggregate market level returns in KSE are quite volatile.

The two important issues regarding stock return volatility i.e. it's exposure to macroeconomic fundamentals, and the asymmetry and leverage behavior are theoretically interlinked (e.g. see Bollerslev, Chou, \& Kroner, 1992; Elyasiani \& Mansur, 1998). In light of the foregoing discussion, this study aims to investigate the impact of the exchange rate, interest rate, market return, and oil returns on daily stock return volatility at a firm level along with the asymmetry and leverage effects of volatility for both NYSE and PSX on comparative bases.

\subsection{Motivations for size and age effect}

The behavior of stock return volatility to various macroeconomic fundamentals and the asymmetry and leverage effect of firms in both developed and emerging markets may differ with respect to firm features such as its size and age (Jiang, Chua, 
Kotabe, \& Murray, 2011) . For instance, Baker and Wurgler (2006) argued that the investors pick the stocks based on firm characteristics rather than its statistical properties outlined by Markowitz (1959). Moreover, keeping these firms' features as the critical factors in investment and policy decisions, the studies of Narayan and Sharma (2011); Mandimika and Chinzara (2012); and Khan, et al. (2016) proposed the future research to investigate the firm features in this regard. The strong effect of size and age was highlighted by several researchers and categorized into two groups. Researchers ${ }^{6}$ in first group are of the view that large and old firms are more efficient, profitable, less risky and stable than small and young firms. Hence, according to Glancy (1998) and Elyasiani, Mansur, and Pagano (2007) the experienced and skilled management with the support of larger financial resources place the large and old firms in a stronger position to diversify their investment and advantage from the "economies of scale" than their small and young counterparts. On the other stream, for the young and small firms' investors have a very small amount of information; hence in the economic downfall, they are more likely to "short" their stock positions even if these firms were performing well than the old firms (Chun et al., 2008). Fama and French (2004) and later reinforced by Chun et al. (2008), argued that small and young firms have minimal survival rate and are being more exposed to negative effects of fluctuations in economic fundamentals. Abdullah et al. (2012) reported that small and young firms are riskier due to lack of financial and $R \& D$ resources, deprived quality, lack of employees' training $\&$ development and non-existence of qualified and experienced management. In another study, Sharma et al. (2014) argued that as the small firms have limited marketing strategies, hence, they may be more vulnerable to shocks as compared to large firms.

The second group of researchers ${ }^{7}$ have the opposite stance and documented that old firms are symbols of rigidity and inertia which in turn adversely affect the performance of the firm and its employees through the gradual decline of productive efficiency, slowing down of growth, older and outdated capital assets, decline in $R \& D$ and other investment activities, and the bureaucratic system ${ }^{8}$. These firms are comparatively slower in adopting or learning the new technology, innovations, and practices due to the inherent rigidity and moral hazard characteristics (Jiang et al.,

5 See also Moeller, Schlingemann, and Stulz (2004), Chun, Kim, Morck, and Yeung (2008), Loderer and Waelchli (2010) among others.

6 These include Fama and French (2004), Elyasiani et al. (2007), Chun et al. (2008), Huynh and Petrunia (2010), Jiang et al. (2011), Abdullah, Shah, and Khan (2012), Salman and Yazdanfar (2012).

7 For instance, Caves (1998), Moeller et al. (2004), Elyasiani et al. (2007), Loderer and Waelchli (2010), Park et al. (2010), Jiang et al. (2011), Mandimika and Chinzara (2012), Loderer, Stulz, and Waelchli (2013), Uhlaner, Stel, Duplat, and Zhou,(2013).

8 See studies such as Caves (1998), Moeller et al. (2004), Elyasiani et al. (2007), Loderer and Waelchli (2010), Park et al. (2010), Jiang et al. (2011), Mandimika and Chinzara (2012), Loderer, Stulz, and Waelchli (2013), Uhlaner et al. (2013) 
2011). Similarly, the corporate governance worsens as the firms become large and old (Elyasiani et al., 2007; Loderer \& Waelchli, 2010). This increases the internal disputes, decreases internal-control and fallouts in mismanagement despite declines in the firm growth as it becomes older (Caves, 1998). Therefore, according to Loderer and Waelchli (2010), the old age firms might lose their competitive advantage. In addition, the executives of these old firms are less efficient in building social-emotional bonds in contrast to the young firms (Jiang et al., 2011). Moreover, the financial literature regarding firm's size (such as Vickery, 2008) reported that small firms are better in risk management. Similarly, small firms also have better incentive procedures and have more flexible management (Moeller et al., 2004). Moreover, Park et al. (2010) concluded that young and small firms grow faster than the large and old firms. Keeping in view the negligence of existing researchers, Mandimika and Chinzara (2012) and Khan et al. (2016) suggested that future studies should articulate the worth of size and age effect with respect to economic exposure, and asymmetry and leverage behaviour of stock returns, since it will be valuable for the investors for effective decisions. Moreover, as for the firm's features are concerned, there are researchers who also noted asymmetric effects of stock returns with respect to various firm features. For instance, Chun et al. (2008) argued that the negative news related to young and small firms have a greater impact on the investor's valuation of the stocks as compared to the valuation of large and old firms. Therefore, the stock returns of small and young firms are more sensitive than the stock returns of large and old firms.

From the above discussion, it is established that the behavior of small and young firms is quite different from the large and old firms. Therefore, it is the matter of empirical investigation to find exactly what type of dissimilarities they have. Hence, this is important to conclude that there are size and age effects with regard to the impact of macroeconomic fundamentals on stock return volatility and asymmetry and leverage effect of small and young firms vs. large and old firms.

\subsection{Motivations for com paring developed (NYSE) and emerging (PSX) markets $^{9}$}

The institutional infrastructure and form of efficiency of the developed and emerging markets differ from each other (Fuss, 2002). He further argued that traditionally, emerging economies are victims of high external debt, political instability, and strong currency turbulence. Moreover, emerging markets are characterized by higher average returns, low correlations with developed markets, more predictable returns with higher volatility (Bekaert \& Wu, 2000). Al-Jafari, Salameh, and Habbash (2011) concluded that as the structure of both emerging and developed markets are different;

9 Morgan Stanley Capital International (MSCI) categorizes the world markets into emerging and developed markets. 
hence, the stock price movement may also be different. Consequently, the emerging stock returns can respond differently to macroeconomic variables than those of the developed markets. From the investors' perspective, this indicates an opportunity for international diversification of their investments.

However, as pointed by Kizys and Pierdzioch (2009) there is a shortage of studies which considered the linkage between stock market returns and macroeconomic factors, comparing the emerging market with developed markets. Majority of the researchers have investigated the developed and emerging markets in isolation without providing any link between them. A brief survey regarding some of the recent yet very few studies that compared the determinants of stock returns and return volatility of both developed and emerging markets is given as follows. Khanna and Sharma (2012) compared India, UK, and US for the effect of oil prices on stock price movements. Moore and Wang (2014) while exploring the effect of exchange rate on stock prices compared two groups of markets i.e. developed markets (including Australia, Canada, Japan, and the UK) and emerging Asian markets (including Indonesia, Malaysia, South Korea, Philippines, Singapore, and Thailand).

Kundu and Sarkar (2016) while exploring the return-volatility interdependence and asymmetry volatility, considered the data from developed markets (US and UK) and emerging markets (Brazil, Russia, India, and China). They further justified that developed markets are well structured, exercise time-tested and established trading rules, and have strong regulatory authorities. On the other hand, the emerging markets lag behind the developed markets in these aspects. Moreover, with the financial integration of economies, the cross-country dependencies are now more significant in international portfolio choices and investment decision. Therefore, the market conditions of varying effects on stock return volatility are crucial in making an appropriate investment decision. Similarly, a comparative study between Sri Lankan stock market (emerging market) and London Stock Exchange (developed market) was conducted by Menike, Dunusinghe, and Ranasinghe (2015) to explore the country-specific and firm-specific determinants of stock returns. They argued that this parallel comparison is important as the LSE is highly developed market as compared to CSE and Sri Lankan state can learn and formulate better strategies to improve their economic fundamentals, stock market performance and consequently, lead towards stability of the economy. Keeping in view the above discussion, the current study also aims to establish a link between developed and emerging market with respect to the impact of macroeconomic factors and asymmetry and leverage effect.

\subsection{Significance of the study}

This study contributes to both theory and practice. Theoretically, this study adds to the existing literature in three different ways. Firstly, very limited literature is available that empirically investigates the relationship between macroeconomic factors 
and stock return volatility and its dynamics, particularly in the context of developing economies (Mahmud \& Mirza, 2011; Qayyum \& Anwar, 2011; Ho \& Lyke, 2017). Hence, the current study addresses this deficiency. Secondly, most of studies even in the developed markets have only considered market or sectoral level stock data for empirical investigation ${ }^{10}$. Unfortunately, the aggregate or market level analysis is not capable to provide clear and unbiased results which leads to ineffective decision (Chinzara, 2011; Sharma et al., 2014; Khan et al., 2016). The current study considers the firm level daily data with respect to firm's size and age. Finally, it is now established that stock markets of developing economies behave differently from those of developed economies (refer to section 1.5). Therefore, the current study investigates all the dimensions with respect to developed (NYSE) and emerging (PSX) markets. Practically, the performance of the stock market and the economy are closely linked. Hence, the determinants of stock return volatility will surely help the investment analyst, economists and policy makers in government to predict the future economic growth. Moreover, local and foreign investors would be able to formulate strategies to mitigate their risk by utilizing portfolio diversification, risk management and hedging (across the NYSE and PSX).

The rest of the study is layout as follows: Section 2 presents the empirical model, analytical procedure, data, and methodology. In section 3, results and discussion of the analysis are presented. Finally, section 4 concludes the research study.

\section{Em pirical Models, Analytical Procedure, Data, and Methodology}

The empirical work conducted so far in the context of both developed and emerging markets have exhibited a strong impact of exchange rate, market return, oil price, and risk free rate, etc. on stock returns and its volatility ${ }^{11}$. The current study attempts to explore the effect of these economic variables on stock return volatility at the firm level which is also further studied with regard to firm's size and age in both a developed market (NYSE) and emerging market (PSX). Moreover, the current study also aims to examine the asymmetric and leverage effect at the firm level ${ }^{12}$. To analyze the macroeconomic impact on stock return volatility, the current study applies the following "general" model:

$$
\mathrm{V}_{\mathrm{f}, \mathrm{t}}=\beta_{0}+\beta_{1} \mathrm{X}_{1}+\beta_{2} \mathrm{X}_{2}+\beta_{3} \mathrm{X}_{3}+\ldots \ldots \ldots \ldots+\varepsilon_{\mathrm{t}}
$$

10 For instance, see Chowdhury, Mollik, and Akhter (2006), Adam and Tweneboah (2009), Adjasi (2009), Chinzara (2011), Elyasiani et al. (2011), Walid, Chaker, Masood, and Fry (2011), Iqbal (2012), Kumari and Mahakud (2015), Choi and Yoon (2015) among others.

11 For example, see the empirical studies of Joseph (2002), Joseph and Vezos (2006), Liow, Ibrahim, and Huang (2006), Elyasiani et al. (2011). 
Where: $\mathrm{V}_{\mathrm{f}, \mathrm{t}}=$ Stock Return Volatility; $\mathrm{X}=$ Macroeconomic Variables

\subsection{Data and methodology}

The daily stock prices of the firms fulfilling the conditions set by this study from both PSX and NYSE (via GICS coding system) are collected from $3^{\text {rd }}$ January 2000 to $31^{\text {st }}$ December 2015. More precisely, to qualify, the firms must be listed and actively trading for the entire data period and the data regarding their date of listing and market capitalization must also available. Further for firm size and age, the existing financial literature ${ }^{13}$ is followed and firms are categorized into four groups based on their size and age. The firm size is determined by the daily market capitalization of the individual firm at the starting date ( $3^{\text {rd }}$ January 2000) of the sample period. Similarly, the age of a firm is measured by the date of the firm when it is first incorporated (see Fink, Fink, Grullon, \& Weston, 2006; Brown \& Kapadia, 2007; Sagi \& Seasholes, 2007). Moreover, size and age groups 1 represent the smallest and youngest firms; whereas, size and age groups 4 represent the largest and oldest firms. In case of NYSE, the data for S\&P 500 Index and for all the firms closing daily stock prices have been extracted from Thomson Banker's ONE for 3,985 days and for PSX, the data for KSE100 and all stocks are taken from "Opensource.com".

Importantly, the data collected for all these variables are daily. The choice of daily data is based on three fundamental reasons ${ }^{14}$. First, the non-trading days and thin trading raise require considering daily stock prices. Moreover, the speed at which equity prices integrated new information also makes daily data a suitable choice, especially given their ability to capture daily trading information dynamics. Therefore, following Chinzara and Aziakpono (2009); and Mandimika and Chinzara (2012), all the non-trading days are excluded from the data. Second, a high-frequency study on stock prices is always desired as they change in response to many financial and economic forces (see Hammoudeh, Dibooglu, \& Aleisa, 2004; El-Sharif, Brown, Burton, Nixon, \& Russell, 2005; Bachmeier, 2008; Sari, Hammoudeh, \& Soytas, 2010). Third, the use of daily data provides an opportunity to observe longer historical periods which can subsequently offer better insight into long-term volatility movements (Elyasiani \& Mansur, 1998).

\subsection{Analytical procedure}

Following the financial literature (Elyasiani, Mansur, \& Odusami, 2011; Man-

13 Such as: Fama and French (2004), Chun et al. (2008), Narayan and Sharma (2011), Sharma et al. (2014), Khan et al. (2016).

14 Daily data is also used by: Ahmed (2008), Narayan and Narayan (2010), Narayan and Sharma (2011),Mollick and Assefa (2013), Kang et al. (2015), Kundu and Sarkar (2016), Epaphra (2017). 
dimika \& Chinzara, 2012; Khan et al., 2016), the "log returns" are calculated from daily data; this helps in mitigating the problems of non-stationarity, heteroskedasticity, autocorrelation, and multicollinearity (Gujarati, 2004). The analytical process further divides the investigation into three stages. The $1^{\text {st }}$ stage examines the whole data with respect to temporal characteristics to determine the normality of the data, serial correlation with volatility clustering and heteroskedasticity. Moreover, the two most popular unit root tests i.e. ADF and PP are applied to check the time series data for unit root issues ${ }^{15}$. Having checked the order of integration for each variable of the study, the next step is to investigate the observations for the possible relations of economic variables and stock return volatility. In the $2^{\text {nd }}$ stage, the above multifactor GARCH $(1,1)$ equation is tested for each of the firm level stock returns separately. Finally, the $3^{\text {rd }}$ stage revolves around investigating the asymmetry and leverage effect by employing the EGARCH model at each of the firm level return volatility.

\subsection{GARCH $(1,1)$ model}

Time series data is characterized by volatility clustering, leptokurtosis, hetero-scedasticity, serial correlation, and non-normality (Mandelbrot, 1963; Fama, 1965). These problems are well addressed by ARCH model (Mandimika \& Chinzara, 2012), independently developed by Engle (1982). Later, Bollerslev (1986) enhanced ARCH model to a generalised ARCH (GARCH) model. In GARCH, the current conditional variance is the function of the previous square error term and past conditional variances. The GARCH ( $\mathrm{p}, \mathrm{q})$ with $\mathrm{p}=1$ and $\mathrm{q}=1$ can be adequately employed in any financial time-series to grasp the dynamics of volatility (e.g. see Lamoureux \& Lastrapes, 1990; Elyaisani et al. 2011; Fah, Nassir, \& Chowdhury, 2011). Following the existing financial press ${ }^{16}$; this study also applies $\operatorname{GARCH}(1,1)$ model to examine the impact of economic factors on stock return volatility ${ }^{17}$. Similarly, Fah et al. (2011) and Lee, Nguyen, and Sy $(2017)$ stated that $(1,1)$ is the most acceptable, agreed and suitable order for applying GARCH model. Moreover, it is also apparent from Schwarz Information Criterion (SIC) that lag 1 is the most suitable lag. Following is the general univariate equation of $\operatorname{GARH}(1,1)$ :

$$
\begin{aligned}
& \mathrm{r}_{\mathrm{t}}=\mathrm{u}_{\mathrm{i}}+\sum_{i=1}^{k} \alpha_{i} r_{t-i}+\varepsilon_{t}, \frac{\varepsilon_{t}}{I_{t-1}} \sim N\left(0, h_{t}\right)----- \\
& \mathrm{h}_{\mathrm{t}}=\omega+\sum_{i=1}^{p} \alpha_{i} \varepsilon_{t-i}^{2}+\sum_{j-1}^{q} \beta_{j} h_{t-j}, \omega>0, \mid \alpha_{i}+\beta_{j} \mathrm{k} 1
\end{aligned}
$$

15 Descriptive Statistics are provided and discussed in a separate appendix due to space limitations. 16 See for instance, Lamoureux and Lastrapes (1990), Engle and Patton (2001), Liow et al. (2006), Goudarzi and Ramanarayanan (2010), Elyaisani et al. (2011), Narayan and Sharma (2011), Sharma et al. (2014), Lee, Nguyen, and Sy (2017).

17 For inspection purpose, when various orders in GARCH model are tested for the returns series in this study, GARCH $(1,1)$ is found the most appropriate model to Pakistani data. 
Equation-2 represents mean equation where current innovation is a function of previous innovation. $I_{t-1}$ holds zero mean, a variance $h_{t}$ and is serially uncorrelated. Moreover, $r_{t-I}$ is the lagged and $r_{t}$ is the current returns. Whereas, equation- 3 is the variance equation of GARCH (p, q), where the $h_{t}$ represents the conditional variance; $\omega$ indicates the constant; the parameter of lagged-square residuals developed from mean equation $\left(\varepsilon_{t-1}^{2}\right)$ are represented by $\alpha_{i}$ but $\beta_{j}$ holds the representation of coefficient of lagged-conditional variances. Literature in finance holds the economic theory backing such variations in conditional variances of stocks (Lamoureux \& Lastrapes, 1990; Bollesrev et al., 1992; Elyasiani \& Mansur, 1998).

\subsection{EGARCH model}

The basic GARCH model is "symmetric" and doesn't capture the "asymmetry effect" which is inherent in most of the volatility of the stock. In the financial environment, asymmetric and leverage effect refers to the characteristic of time series on stock prices that "bad news" tends to increase volatility more than "good news" (Black, 1976; Nelson, 1991). Nelson (1991) significantly contributed by introducing the Exponential GARCH model (EGARCH). It has the ability to pick the "asymmetric volatility" of stock returns. It distinctly shows how does stock return volatility is affected by the good news and bad news of the same magnitude (Ewing et al., 2005; Mandimika \& Chinzara, 2012). Consistent with the financial literature (e.g. Braun, Nelson, \& Sunier, 1995; Ewing et al., 2005; Mandimika \& Chinzara, 2012 etc. $^{18}$ ), this study also applies EGARCH model to investigate the asymmetric response of stock return volatility. Particularly, in EGARCH model the natural log of the conditional variance is allowed to change over time as a function of the lagged error terms rather than lagged squared errors (Magnus \& Fosu, 2006). Below is the general equation of EGARCH model as denoted by Ewing et al. (2005) and Mandimika and Chinzara (2012):

$$
\begin{aligned}
& \log \left(h_{\mathrm{t}}\right)=\omega+\sum_{i=1}^{q} \alpha_{\mathrm{i}}\left[\left|\frac{\varepsilon_{t-i}}{\sqrt{h_{t-i}}}-E\left(\frac{\varepsilon_{t-i}}{\sqrt{h_{t-i}}}\right)\right|\right]+\sum_{k=1}^{m} \gamma_{k} \frac{\varepsilon_{t-k}}{\sqrt{h_{t-k}}}+\sum_{j=1}^{p} \beta_{j} \log h_{t-j},------(4) \\
& \omega>0,\left|\alpha_{i}+\beta_{j}\right|<1 ; \gamma_{k}<0, \text { if volatility is asymmetric }
\end{aligned}
$$

Where, in equation (4), $\alpha_{i}$ and $\beta_{j}$ have the same meaning as in the equation of GARCH $(1,1)$. Further, in case the coefficient $\gamma_{k} \# 0$, the volatility will be asymmetric; however, when $\gamma_{k}<0$, then the negative news has a greater role in increasing stock returns volatility than positive news of the same magnitude. Finally, if $\gamma_{k}>0$, in such case the positive news have a stronger impact in increasing stock return volatility than the negative news of the same magnitude (Brooks, 2008; Ewing et al., 2005; Man-

18 Most of these studies found EGACRH as the best-fitted model to capture the asymmetry and leverage effect in context of Pakistan (see Saleem, 2007; Arshad et al.,2012). 
dimika \& Chinzara, 2012). Various studies in the developed and emerging markets have concluded the suitability of EGARCH model (e.g. see Rossetti et al., 2017).

\section{Results and Discussion}

The GARCH $(1,1)$ and EGARCH equations are applied for each firm in each size and age group and computed the percentages. Moreover, the number of firms and their percentages are given for only those firms for which the results are either positively or negatively "significant" in each equation. All the results are then orga-

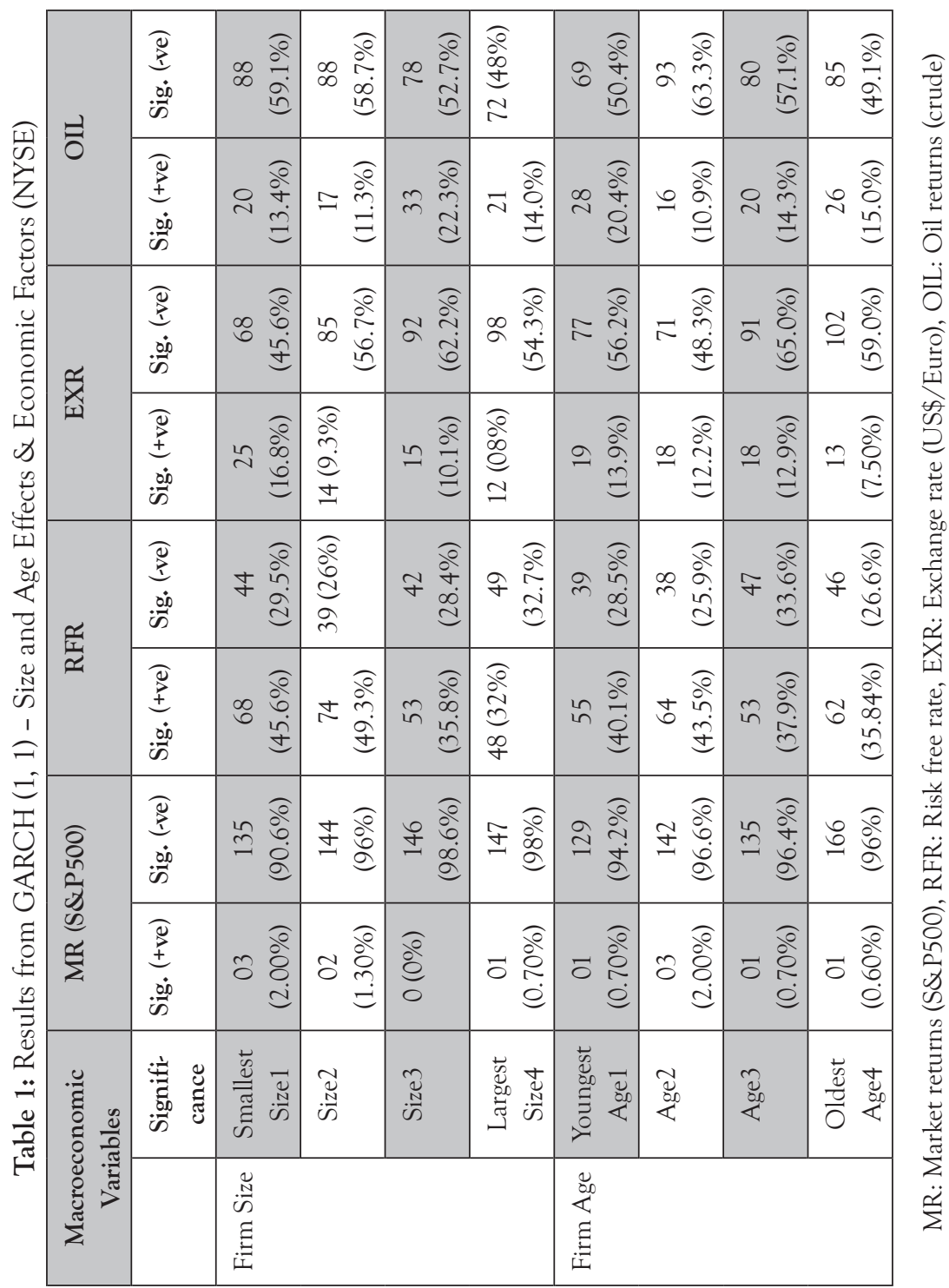




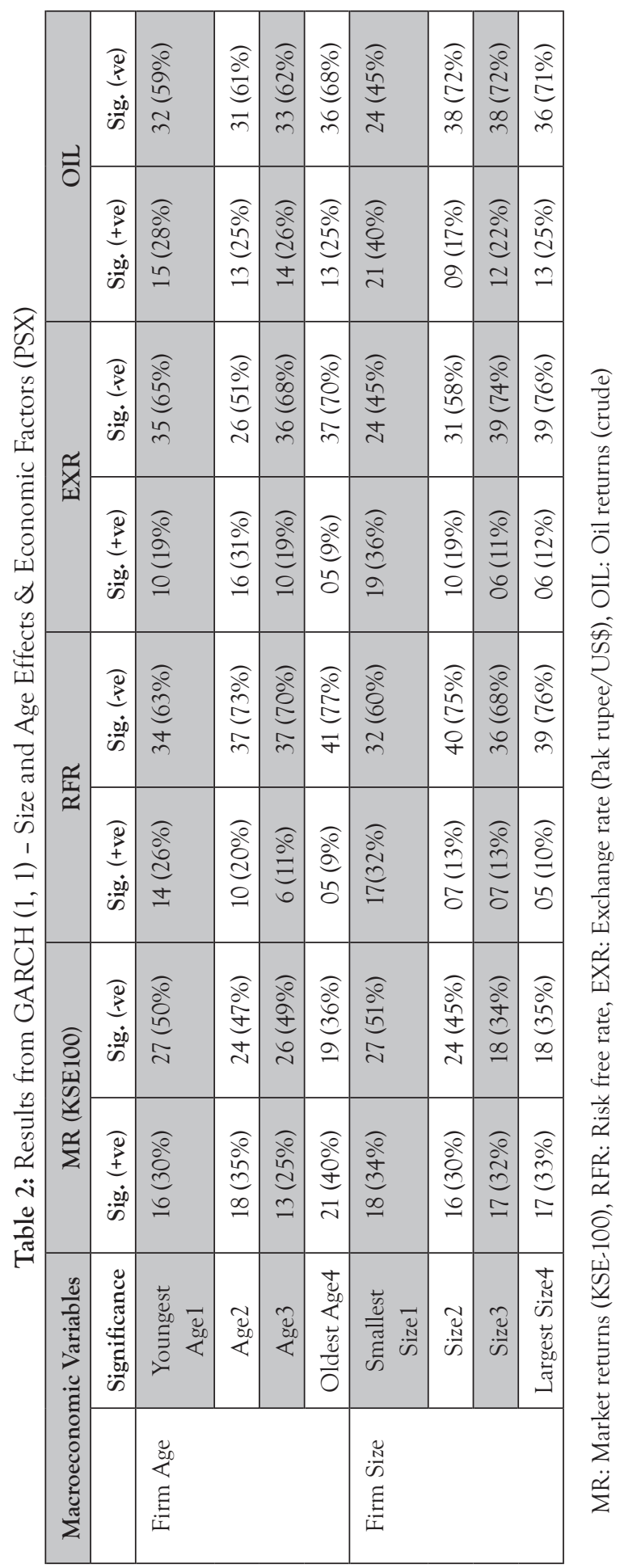


nized into the following tables (Table 1 through Table 4) and some important and interesting findings were noticed. These findings and the discussions on these findings are further reported for NYSE and PSX on comparative bases.

\subsection{Stock return volatility and macroeconomic conditions with respect to size and age of the firms}

There are two important findings revealed by the results with regard to market return (MR). The first is related to the "sign effect"; in both the NYSE and the PSX markets, significant negative impact of $\mathrm{MR}$ is prominent and visible in a higher percentage of firms (Table 1 and 2). The second finding is related to "changing effect". Unlike the sign effect, changing effect is different in both the markets, i.e. for NYSE as the size and age of firms grow from small to large and from young to old, the negative significant effect also increases (Table 1); however, for PSX as the size and age of firms increase, the negative significant effect decreases and converts to positive significant effect (Table 2). These results show that size and age of the firm carry opposite effects for both the markets.

The market return in both the NYSE (S\&P500) and PSX (KSE100) represents the average return of top firms in these markets. Hence, an increase in market return leads to an increase in the investors' confidence and optimism about the shared market as a whole. Consequently, all this positively affects the stock prices and in turn also decreases the stock return volatility (see Liow, 2004). Further, as seen in Table 1, for NYSE firms, the negative effect increases with the increase in size and age and it clearly indicates that the investors prefer to invest more in the stocks of large and old firms as large and old firms are considered having a stronger position to diversify their investment (Elyasiani et al., 2007; Huynh \& Petrunia, 2010; Jiang et al., 2011 among others). Similarly, as reported by Glancy (1998), large and old firms are seen more safe, liquid and credible than the small and young firms. So, all this put downward pressures on stock return volatility of large and old firms.

On the other hand, this reacts exactly in opposite direction in the context of Pakistan i.e. with the increase in size and age of firms; the market return shows a positive impact in more firms than the small and young firms. Hence, in PSX the anti-thesis regarding size and age of the firm proves valid. More specifically, as argued by some researchers that large and old firms are comparatively slower in adopting or learning the new technology, innovations, and practices due to the inherent rigidity and moral hazard characteristics (see Mandimika \& Chinzara 2012; Loderer et al., 2013; Uhlaner et al., 2013); hence, their return volatility is affected more than the small and young firms. 
The risk-free rate (RFR) has exhibited entirely different results with regard to the sign and changing effect for both the markets. For the NYSE firms in all size groups (except size 4), a higher number of firms are found with a positive and significant effect of RFR on stock return volatility whereas, for PSX a substantial number of firms have shown a negative significant effect for the same variable. More specifically, as the size and age of NYSE firms gradually increase (see Table 1), the number/ percentage of firm decreases with positive significant effect of RFR on stock return volatility. However, the percentage of firms with a negative significant impact of RFR increases with the increase in both size and age of firms. Any increase in the interest rates affects negatively the investors holding stocks of different firms (see Mukherjee \& Naka, 1995; Joseph, 2002; Butt, Rehman, Khan, \& Safwan, 2010). This is because for the investors it is more attractive to deposit their money in the banks and earn more profit without taking any risk. So, in the result of an increase in interest rates will make the investors demand more required rate of return and the volatility of the shares will also increase.

However, in context of PSX (Table 2), the investors considering the small and young firms as riskier, demand more required rate of return from small size and young firms than large and old firms. Therefore, the small and young firms' return volatility has shown a positive relationship with interest rates more than the large and old firms. Moreover, in PSX the percentage of firms with a negative impact on stock return volatility gradually increases as the size and age of the firm increase from small to large and from young to old. This reconfirms ${ }^{19}$ the investors' confidence in large and old firms and considering them safer as compared to small and young firms.

Unlike MR and RFR, the exchange rate (EXR) behaved in the same way for both NYSE and PSX (Table 1 and 2). More specifically, in both the markets, for a majority of the firms from all the size and age groups the EXR exhibited a negative significant effect on the stock return volatility. Similarly, the percentage of firms with negative significant effect increases as the size and age groups increase from small to large and from youngest to oldest in both the markets.

From the "sign effect" perspective, in Table 1 and 2 oil returns have shown a negative significant impact on the stock return volatility for the majority of the firms in all size and age groups of both NYSE and PSX markets. However, from the "changing effect" perspective, an entirely reverse pattern is observed, i.e. for NYSE firms as the size and age increase the percentage of firms with negative significant impact of oil returns decreases. On the other hand, for PSX firms an increase is observed in the percentage of firms with negative significant sign as the size increases from small

19 This behaviour is also confirmed by Elyasiani et al. (2007), Chun et al. (2008), Huynh and Petrunia (2010), Jiang et al. (2011), Abdullahet al. (2012). 
to large. By closely observing the composition of small size and young age groups of firms listed at NYSE, it is revealed that it includes majority of the firms from energy

Table 3: Results from EGARCH $(\gamma)$ - size and age effects (NYSE firms)

\begin{tabular}{|c|c|c|c|c|c|c|c|c|}
\hline \multirow{2}{*}{ Sig. } & \multicolumn{4}{|c|}{ Size of the Firm } & \multicolumn{4}{c|}{ Age of the Firm } \\
\cline { 2 - 9 } & $\begin{array}{c}\text { Smallest } \\
\text { Size1 }\end{array}$ & Size2 & Size3 & $\begin{array}{c}\text { Largest } \\
\text { Size4 }\end{array}$ & $\begin{array}{c}\text { Youngest } \\
\text { Age1 }\end{array}$ & Age2 & Age3 & $\begin{array}{c}\text { Oldest } \\
\text { Age4 }\end{array}$ \\
\hline $\begin{array}{c}\text { Sig. } \\
(+v e)\end{array}$ & $\begin{array}{c}18 \\
(12.08 \%)\end{array}$ & $\begin{array}{c}12 \\
(8 \%)\end{array}$ & $\begin{array}{c}10 \\
(6.76 \%)\end{array}$ & $\begin{array}{c}07 \\
(4.67 \%)\end{array}$ & $\begin{array}{c}09 \\
(6.57 \%)\end{array}$ & $\begin{array}{c}09 \\
(6.12 \%)\end{array}$ & $\begin{array}{c}15 \\
(10.71 \%)\end{array}$ & $\begin{array}{c}13 \\
(7.51 \%)\end{array}$ \\
\hline $\begin{array}{c}\text { Sig. } \\
(-\mathrm{ve})\end{array}$ & $\begin{array}{c}88 \\
(59.06 \%)\end{array}$ & $\begin{array}{c}99 \\
(66 \%)\end{array}$ & $\begin{array}{c}102 \\
(68.92 \%)\end{array}$ & $\begin{array}{c}114 \\
(76 \%)\end{array}$ & $\begin{array}{c}80 \\
(58.39 \%)\end{array}$ & $\begin{array}{c}101 \\
(68.7 \%)\end{array}$ & $\begin{array}{c}98 \\
(70 \%)\end{array}$ & $\begin{array}{c}125 \\
(72.25 \%)\end{array}$ \\
\hline
\end{tabular}

EGARCH: Exponential generalized autoregressive conditional heteroskedasticity model

Table 4: Results from EGARCH $(\gamma)$ - size and age effects (PSX firms)

\begin{tabular}{|c|c|c|c|c|c|c|c|c|}
\hline \multirow{2}{*}{ Sig. } & \multicolumn{4}{|c|}{ Size of the Firm } & \multicolumn{3}{c|}{ Age of the Firm } \\
\cline { 2 - 9 } & $\begin{array}{c}\text { Smallest } \\
\text { Size1 }\end{array}$ & Size2 & Size3 & $\begin{array}{c}\text { Largest } \\
\text { Size4 }\end{array}$ & $\begin{array}{c}\text { Youngest } \\
\text { Age1 }\end{array}$ & Age2 & Age3 & $\begin{array}{c}\text { Oldest } \\
\text { Age4 }\end{array}$ \\
\hline $\begin{array}{c}\text { Sig. } \\
(+v e)\end{array}$ & $22(42 \%)$ & $\begin{array}{c}26 \\
(49 \%)\end{array}$ & $41(77 \%)$ & $36(71 \%)$ & $31(57 \%)$ & $\begin{array}{c}25 \\
(49 \%)\end{array}$ & $\begin{array}{c}30 \\
(57 \%)\end{array}$ & $39(74 \%)$ \\
\hline $\begin{array}{c}\text { Sig. } \\
(-v e)\end{array}$ & $23(43 \%)$ & $\begin{array}{c}19 \\
(36 \%)\end{array}$ & $10(19 \%)$ & $06(12 \%)$ & $16(30 \%)$ & $\begin{array}{c}18 \\
(35 \%)\end{array}$ & $\begin{array}{c}18 \\
(34 \%)\end{array}$ & $07(13 \%)$ \\
\hline
\end{tabular}

EGARCH: Exponential generalized autoregressive conditional heteroskedasticity model

and transport sectors. Our results are in line with Narayan and Sharma (2011) who also reported a positive effect of oil prices on stock returns for higher percentage of firms from small size and young age groups (which gradually decreases with the increase in size and age).

\subsection{Em pirical results regarding asymmetry and leverage effect (evidence from both NYSE and PSX) with respect to size and age of the firm}

In general, the results from EGARCH model showed significant evidence of asymmetry and leverage effects for all firms in NYSE and for a majority of PSX (see Table 3 and 4). More specifically, the bad news increases the stock return volatility in NYSE more than the good news in same market (Table 3). In other words, if the price of a stock falls, the financial leverage increases, leads to an increase in the stock return volatility. Yet another explanation could be in the context of risk and return relationship (see Mandimika \& Chinzara, 2012). In the event of an expected increase in volatility, the expected return also increases which in turn leads to a decline in the share price; this is also termed as "volatility feedback effect" by Karmakar (2007). These results are in line with the earlier studies in US context such as Cheung and 
$\mathrm{Ng}$ (1992) and Duffee (1995). Generally, the leverage and volatility feedback effects work side by side in the market. For example, if there is an anticipation of investors of a particular market that the volatility will increase, they would place more orders to sell than buy orders. This will result in a drop of share price to balance the buying and selling demands. Hence, it is expected that any increase in volatility will lead to an immediate decrease in price (volatility feedback hypothesis as also referred by Karmakar, 2007; Saleem, 2007; Mandimika \& Chinzara, 2012; Khan et al., 2016).

As far as the sign effect is concerned, the asymmetry and leverage effect has shown different results for both the markets with respect to size and age of the firms. More specifically, for the majority of the firms in NYSE, a bad news has a greater effect on the stock return volatility and this effect further increases with the increase in firm's size from small to large or when it grows older from young to old. Now in case of NYSE, it is clearly visible that as the size and age of the firm increases from small to large and from young to old the bad news has a greater effect on the volatility of stock returns than the good news. The larger and older the firm in size and age, the slower it is in adopting or learning the new technology, innovation and practices because of its inherent rigidity and moral hazard features (Jiang et al., 2011). On the other side, small and young firms are better in risk management than large firms (as reported by Vickery, 2008). Similarly, small and young firms have better incentive procedures and have more flexible management than in the case of large firms (Moeller et al., 2004). Even small and young firms have more capacity (sales) to grow faster than the large ones (Park, Shin, \& Kim, 2010). All this proves that small and young firms in the context of US are more capable to absorb the effect of bad news than the large firms.

However, for the case of PSX firms (as reported in Table 4) the good news has a strong effect on the stock return volatility and again this effect increases with the increase in size and age of the firms. Nonetheless, the impact of bad news on the stock return volatility even gradually decreases with the increase in size and age of the firm in PSX. These results signify that in context of Pakistan, large and old firms are highly productive, have experienced management, long historical record of their shares, more $R \& D$ resources, large internal funds, strong market power, availability of inexpensive loans, more liquidity and more credible than their small counterparts (Chun et al., 2008; Khan et al., 2016). On the other hand, small and young firms bear high borrowing costs which in consequence disturb their competitiveness in the market (Huynh \& Petrunia, 2010). Moreover, small and young firms are affected more unfavorably by the rising interest rates and also have minimal survival rate and are being more exposed to the negative effects of fluctuations in the economic factors (Fama \& French, 2004; Chun et al., 2008). Moreover, small and young firms are not dynamic, and less flexible to the environmental changes (Elyasiani et al., 2007; 
Salman \& Yazdanfar, 2012). Sharma et al. (2014) also argued that as the small and young firms have limited marketing strategies, they may be more vulnerable to the shocks as compared to large firms. In light of all this, it is quite evident that small and young firms are riskier and exposed to the bad news more than the good news in the Pakistani context.

\section{Conclusion}

The results from GARCH $(1,1)$ model showed that market returns in both NYSE (S\& P500) and PSX (KSE100) was the most significant of all macroeconomic variables followed by other variables. Further, with respect to size and age, it showed a different effect in both the markets. More specifically, as the size and age increase, the percentage of firms also increases with market return's negative impact on stock return volatility in NYSE and vice versa in case of PSX. Risk-free rate showed a positive effect on the stock return volatility of majority of the firms in all size and age groups of NYSE. However, the percentage of firms gradually decreases with the increase in size and age of the firm. For PSX, RFR has shown a negative impact on the stock return volatility for majority of the firms which gradually increases as the size and age of the firms' increase. Exchange rate showed a significant negative effect on the stock return volatility for majority of the firms in both NYSE and PSX markets. Furthermore, the percentage of firms (with the negative relationship for EXR) gradually increases with the increase in size and age of the firms. Similar results are also observed in PSX where the percentage of firms with negative coefficients for EXR also increases with the increase in size and age of the firm. Finally, the oil returns again proved to be negatively related to stock return volatility of majority of the firms of NYSE and PSX. From the size and age perspective of the firms in NYSE, the percentage of firms with the negative coefficient for oil returns gradually decreases with the increase in size and age of the firms. On the other hand, in case of PSX, the percentage of firms where oil returns have shown positive relationship is gradually increasing with the increase in size and age of the firms.

In the context of NYSE, the percentage of firms in all size and age groups is higher with a negative coefficient of EGARCH. This further confirms that the impact of negative news on the stock return volatility is higher than the positive news in the context of NYSE. Moreover, the impact of negative news on the stock return volatility in context of NYSE also gradually increases with the increase in size and age of the firm. However, in case of PSX, for the majority of the firms in all size and age groups, the coefficients of EGARCH are positive. This shows that the impact of positive news on the stock return volatility is greater than the negative news for PSX. Finally, in context of Pakistan, the impact of positive news on stock return volatility 
increases with the increase in size and age of the firm.

The findings of this study have potential implications for both policy makers and investors. First, policy makers must be aware of the interdependence of macroeconomic factors and stock market volatility. As on the one hand, the excessive volatility in the stock markets may cause capital outflow, which in turn intensify financial and macroeconomic instability. However, on the other hand, this macroeconomic instability itself triggers stock return volatility in the capital markets. Though the effects of macroeconomic variation cannot be avoided, appropriate strategies can be formulated to mitigate their inverse effect on stock markets. Second, for the investors it would be worthwhile to diversify their investment portfolios and risk between developed and emerging stock markets, particularly keeping in view the firm-level features.

Moreover, this study also intoxicates some worthy recommendations for future studies. For instance, the researchers along with the size and age can also consider other features of firms such as trading nature, financial nature and sectoral location while exploring the effect of economic factors on the stock return volatility. Similarly, the lag effect of macroeconomic factors on the stock return volatility might also be worth exploring. Finally, some other important economic factors ${ }^{20}$ such as industrial production, money supply, and inflation can also be used as determinants of stock return volatility.

\section{References}

Abdullah, F., Shah, A., \& Khan, S. U. (2012). Firm performance and the nature of agency problems in insiders-controlled firms: Evidence from Pakistan. The Pakistan Development Review, 51(4), 161-182.

Adam, M., \& Tweneboah, G. (2009). Foreign direct investment and stock market development: Ghana's evidence. International Research Journal of Finance and Economics, 26(1), 178-185.

Adjasi, C. K. (2009). Macroeconomic uncertainty and conditional stock-price volatility in frontier African markets: Evidence from Ghana. The Journal of Risk Finance, 10(4), 333-349.

Ahmed, S. (2008). Aggregate economic variables and stock markets in India International Research Journal of Finance and Economics, 14(1), 141-164.

Ali, H., \& Shahid, M. A. (2017). The Impact of Interest Rate and Exchange Rate Volatility on Banks' Stock Returns and Volatility: Evidence from Pakistan. International Journal of Commerce and Management, 2(4), 29-39.

Ali, R., \& Afzal, M. (2012). Impact of global financial crisis on stock markets: Evidence from Pakistan and India. Journal of Business Management and Economics, 3(7), 275-282.

20 The current study couldn't consider these because their data was unavailable at daily frequency. 
Al-Jafari, M. K., Salameh, R. M., \& Habbash, M. R. (2011). Investigating the relationship between stock market returns and macroeconomic variables: evidence from developed and emerging markets. International Research Journal of Finance and Economics, 79(1), 6-30.

Angelidis, T., Degiannakis, S., \& Filis, G. (2015). US stock market regimes and oil price shocks. Global Finance Journal, 28(1), 132-146.

Arestis, P., Demetriades, P. O., \& Luintel, K. B. (2001). Financial development and economic growth: the role of stock markets. Journal of money, credit, and banking, 3(1), 16-41.

Arshad, A., Rani, H., \& Shaikh, A. W. (2012). Volatility modeling of Karachi Stock Exchange. Sindh University Research Journal, 44(1), 1125-1130.

Bachmeier, L. (2008). Monetary policy and the transmission of oil shocks. Journal of Macroeconomics, 30(4), 1738-1755.

Baker, M., \& Wurgler, J. (2006). Investor sentiment and the cross-section of stock returns. The Journal of Finance, 11(4), 1645-1680.

Bekaert, G., \& Harvey, C. R. (1997). Emerging equity market volatility. Journal of Financial Economics, 43(1), 29-77.

Bekaert, G., \& Wu, G. (2000). Asymmetric volatility and risk in equity markets. The Review of Financial Studies, 13(1), 1-42.

Bhowmik, D. (2013). Stock market volatility: An evaluation. International Journal of Scientific and Research Publications, 3(10), 1-17.

Bilson, C. M., Brailsford, T. J., \& Hooper, V. J. (2001). Selecting macroeconomic variables as explanatory factors of emerging stock market returns. Pacific-Basin Finance Journal, 9(4), 401-426.

Black, F. (1976). Studies in stock price volatility changes. Proceedings of the 1976 Business Meetings of the Business and Economics Section, American Statistical Association, Boston, MA, USA, 177-181.

Bollerslev, T. (1986). Generalized autoregressive conditional heteroskedasticity. Journal of Economics, 31(3), 307-327.

Bollerslev, T., Chou, R. Y., \& Kroner, K. F. (1992). ARCH modeling in finance: A review of the theory and empirical evidence. Journal of econometrics, 52(1-2), 5-59.

Braun, P. A., Nelson, D. B., \& Sunier, A. M. (1995). Good news, bad news, volatility, and beta. The Journal of Finance, 5(1), 1575-1603.

Brooks, C. (2008). Introductory Econometrics for Finance. Cambridge: Cambridge University Press.

Brown, G., \& Kapadia, N. (2007). Firm-specific risk and equity market development. Journal of Financial Economics, 84(1), 358-388.

Butt, B. Z., Rehman, K., Khan, M. A., \& Safwan, N. (2010). Do economic factors influence stock 
returns? A firm and industry level analysis. African Journal of Business Management, 4(5), 583-593.

Caves, R. E. (1998). Industrial organization and new findings on the turnover and mobility of firms. Journal of Economic Literature, 36(1), 1947-1982.

Chen, Z., Du, J., Li, D., \& Ouyang, R. (2013). Does foreign institutional ownership increase return volatility? Evidence from China. Journal of Banking $\mathcal{E}$ Finance, 37(2), 660-669.

Cheung, Y. W., \& Ng, L. (1992). Stock price dynamics and firm size: An empirical investigation. The Journal of Finance, 47(1), 1985-1997.

Chiang, T. C., \& Doong, S. C. (2001). Empirical analysis of stock returns and volatility: Evidence from seven Asian stock markets based on TAR-GARCH model. Review of Quantitative Finance and Accounting, 17(3), 301-318.

Chinzara, Z. (2011). Macroeconomic uncertainty and conditional stock market volatility in South Africa. South African Journal of Economics, 79(1), 27-49.

Chinzara, Z., \& Aziakpono, M. J. (2009). Dynamic returns linkages and volatility transmission between South African and world major stock markets. Studies in Economics and Econometrics, 33(3), 69-94.

Choi, K. H., \& Yoon, S. M. (2015). The effect of money supply on the volatility of Korean stock market. Modern Economy, 6(5), 535.

Chowdhury, S., Mollik, A., \& Akhter, M. (2006). Does predicted macroeconomic volatility influence stock market volatility? Evidence from the Bangladesh capital market. The European Journal of Management and Public Policy, 5(2), 111-120.

Christie, A. A. (1982). The stochastic behaviour of common stock variances: Value, leverage and interest rate effects. Journal of Financial Economics, 10(4), 407-432.

Chun, H., Kim, J.W., Morck, R., \& Yeung, B. (2008). Creative destruction and firm-specific performance heterogeneity. Journal of Financial Economics, 89(1), 109-135.

El-Sharif, I., Brown, D., Burton, B., Nixon, B., \& Russell, A. (2005). Evidence on the nature and extent of the relationship between oil prices and equity values in the UK. Energy Economics, 27(6), 819-830.

Elyasiani, E., \& Mansur, I. (1998). Sensitivity of bank stock returns distribution to changes in the level and volatility of interest rate: A GARCH-M model. Journal of Banking $\mathcal{E}$ Finance, 22(5), 535-563.

Elyasiani, E., Mansur, I., \& Odusami, B. (2011). Oil price shocks and industry stock returns. Energy Economics, 33(5), 966-974.

Elyasiani, E., Mansur, I., \& Pagano, M. S. (2007). Convergence and risk-return linkages across financial service firms. Journal of Banking $\mathcal{E}$ Finance, 31(4), 1167-1190.

Engle, R. F. (1982). Autoregressive conditional heteroscedasticity with estimates of the variance of United Kingdom inflation. Econometrica: Journal of the Econometric Society, 50(1) 987-1007. 
Engle, R. F., \& Patton, A. J. (2001). What good is a volatility model? Quantitative Finance, 1(1), 237-245.

Ewing, B. T., Kruse, J. B., \& Thompson, M. A. (2005). Comparing the impact of news: A tale of three health care sectors. Journal of Business Finance $\mathcal{E}$ Accounting, 32(7), 1587-1611.

Fah, L. W., Nassir, A. B. M., \& Chowdhury, T. H. S. (2011). Insider trading and market volatility: Evidence from Malaysia. Interdisciplinary Journal of Research in Business, 1(6), 18-43.

Fama, E. F. (1965). The behavior of stock-market prices. Journal of Business, 38(1), 34-105.

Fama, E. F., \& French, K. R. (2004). New lists: Fundamentals and survival rates. Journal of Financial Economics 73(2), 229-269.

Fink, J., Fink, K. E., Grullon, G., \& Weston, J. (2006). Firm age and fluctuations in idiosyncratic risk. Working Paper, Rice University.

French, M. W., \& Sichel, D. E. (1993). Cyclical patterns in the variance of economic activity. Journal of Business $\mathcal{E}$ Economic Statistics, 11(1), 113-119.

Fuss, R. (2002, July). The financial characteristics between emerging and developed equity markets. In Proceedings of Policy Modelling International Conference.

Giri, A., \& Pooja, J. O. S. H. I. (2017). The impact of macroeconomic indicators on indian stock prices: An empirical analysis. Studies in Business and Economics, 12(1), 61-78.

Glancy, K. (1998). Determinants of growth and profitability in small entrepreneurial firms. International Journal of Entrepreneurial Behaviour \& Research, 4(1), 18-27.

Goudarzi, H., \& Ramanarayanan, C. S. (2010). Modeling and estimation of volatility in Indian stock market. International Journal of Business and Management, 5(2), 85-98.

Gujarati, D. N. (2004). Basic Econometrics (4th ed.). Boston: Mc Graw-Hill Companies.

Hameed, A., \& Ashraf, F. (2006). Stock market volatility and weak-form efficiency: Evidence from an emerging market. The Pakistan Development Review, 45(4), 1029-1040.

Hammoudeh, S., Dibooglu, S., \& Aleisa, E. (2004). Relationships among US oil prices and oil industry equity indices. International Review of Economics $\mathcal{E}$ Finance, 13(4), 427-453.

Hammoudeh, S., Yuan, Y., Chiang, T., \& Nandha, M. (2010). Symmetric and asymmetric us sector return volatilities in presence of oil, financial and economic risks. Energy Policy 38(8), 3922-3932.

Hasan, M. A., \& Zaman, A. (2017). Volatility nexus between stock market and macroeconomic variables in bangladesh: An extended garch approach. Scientific Annals of Economics and Business, 64(2), 233-243.

Ho, S. Y., \& Njindan Iyke, B. (2017). Determinants of stock market development: a review of the literature. Studies in Economics and Finance, 34(1), 143-164.

Huynh, K. P., \& J.Petrunia, R. (2010). Age effects, leverage, and firm growth. Journal of Economic Dynamics 
E Control, 34(5), 1003-1013.

Iqbal, J. (2012). Stock market in pakistan: An overview. Journal of Emerging Market Finance, 11(1), 61-91.

Jiang, C. X., Chua, R. Y., Kotabe, M., \& Murray, a. J. Y. (2011). Effects of cultural ethnicity, firm size, and firm age on senior executives' trust in their overseas business partners: Evidence from China. Journal of International Business Studies, 42(9), 1150-1173.

Joseph, N. (2002). Modeling the impacts of interest rate and exchange rate changes on UK stock returns. Derivatives Use, Trading, and Regulation, 7(1), 306-323.

Joseph, N. L., \& Vezos, P. (2006). The sensitivity of US banks' stock returns to interest rate and exchange rate changes. Managerial Finance, 32(2), 182-199.

Kang, W., Ratti, R. A., \& Yoon, K. H. (2015). The impact of oil price shocks on the stock market return and volatility relationship. Journal of International Financial Markets, Institutions, and Money, 34(1), 41-54.

Karmakar, M. (2007). Modeling conditional volatility of the Indian stock market. South Asia Economic Journal, 30(3), 99-116.

Kearney, C., \& Daly, K. (1998). The causes of stock market volatility in Australia. Applied Financial Economics, 8(6), 597-605.

Khan, F., Anuar, M. A., Choo, L. G., \& Bokhari, S. A. M. (2014a). Economic exposure of stock returns on Karachi stock exchange: Substantiation from both aggregate and disaggregate data. International Journal of Information Processing and Management, 5(2), 25-39.

Khan, F., Rehman, S. U., Khan, H., \& Xu, T. (2016). Pricing of risk and volatility dynamics on an emerging stock market: evidence from both aggregate and disaggregate data. Economic research-Ekonomska istralivanja, 29(1), 799-815.

Khan, F., Khan, S. U. R., \& Khan, H. (2016b). Pricing of risk, various volatility dynamics and macroeconomic exposure of firm returns: New evidence on age effect. International Journal of Economics and Financial Issues, 6(2), 551-561.

Khanna, K., \& Sharma, N. (2012). Crude oil price velocity \& stock market ripple: A comparative study of BSE with NYSE \& LSE. International Journal of Exclusive Management Research, 2(7), 1-7.

Kirui, E., Wawire, N. H., \& Onono, P. O. (2014). Macroeconomic variables, volatility, and stock market return a case of Nairobi securities exchange, Kenya. International Journal of Economics and Finance, 6(8), 214-228.

Kizys, R., \& Pierdzioch, C. (2009). Changes in the international comovement of stock returns and asymmetric macroeconomic shocks. Journal of International Financial Markets, Institutions and Money, 19(2), 289-305.

Koutoulas, G., \& Kryzanowski, L. (1996). Macroeconomic factor conditional volatility, time-varying risk premia and stock return behavior. Financial Review, 31(1), 169-195. 
Kumari, J., \& Mahakud, J. (2015). The relationship between the conditional volatility of domestic macroeconomic factors and conditional stock market volatility: Some further evidence from India. Asia-Pacific financial markets, 22(1), 87-111.

Kundu, S., \& Sarkar, N. (2016). Return and volatility interdependences in up and down markets across developed and emerging countries. Research in International Business and Finance, 36(1), 297-311.

Lamoureux, C. G., \& Lastrapes, W. D. (1990). Heteroskedasticity in stock return data: Volume versus GARCH effect. The Journal of Finance, 45(1), 221-229.

Lee, S. K., Nguyen, L. T., \& Sy, M. O. (2017). Comparative study of volatility forecasting models: The case of Malaysia, Indonesia, Hong Kong and Japan stock markets. Economics, 5(4), 299-310.

Liow, K. H. (2004). Time-varying macroeconomic risk and commercial real estate: An asset pricing perspective. Journal of Real Estate Portfolio Management, 10(1), 47-58.

Liow, K. H., Ibrahim, M. F., \& Huang, Q. (2006). Macroeconomic risk influences on the property stock market. Journal of Property Investment and Finance, 24(4), 295-323.

Loderer, C., \& Waelchli, U. (2010). Firm age and performance. Working Paper University of Bern, Switzerland.

Loderer, C., Stulz, R., \& Waelchli, U. (2013). Limited managerial attention and corporate aging. National Bureau of Economic Research Working Paper Series NO. 19428.

Magnus, F. J., \& Fosu, O. E. (2006). Modeling and forecasting volatility of returns on the Ghana stock exchange using GARCH models. American Journal of Applied Sciences, 3(10), 2042-2048.

Mahmud, M., \& Mirza, N. (2011). Volatility dynamics in an emerging economy: Case of Karachi stock exchange. Economic Research, 24(4), 51-64.

Mamtha, D., \& Srinivasan, K. S. (2016). Stock market volatility-conceptual perspective through literature survey. Mediterranean Journal of Social Sciences, 7(1), 208-212.

Mandelbrot, B. (1963). The variation of certain speculative prices. Journal of Business, 36(4), 394-419.

Mandimika, N. Z., \& Chinzara, Z. (2012). Risk-returns trade-off and behaviour of volatility on the South African stock market: Evidence from both aggregate and disaggregate data. South African Journal of Economics, 80(3), 345-366.

Mangani, R. (2008). Modeling return volatility on the JSE securities exchange of South Africa. African Finance Journal, 10(1), 55-71.

Markowitz, H. (1959). Portfolio selection, efficient diversification of investment. Yale University Press. New Haven, CT.

Menike, L. M. C. S., Dunusinghe, P. M., \& Ranasinghe, A. (2015). Macroeconomic and firm-specific determinants of stock returns: A comparative analysis of stock markets in Sri Lanka and in the 
United Kingdom. Journal of Finance and Accounting, 3(4), 86-96.

Moeller, S. B., Schlingemann, F. P., \& Stulz, R. M. (2004). Firm size and the gains from acquisitions. Journal of Financial Economics 73(2), 201-228.

Moore, T., \& Wang, P. (2014). The dynamic linkage between real exchange rates and stock prices: Evidence from developed and emerging Asian markets. International Review of Economics $\mathcal{E}$ Finance, 29(1), 1-11.

Mukherjee, T. K., \& Naka, A. (1995). Dynamic relations between macroeconomic variables and the Japanese Stock Market: An application af a vector error correction model. Journal of Financial Research 18(2), 223-237.

Mushtaq, R., Shah, S. Z. E., Rehman, M. Z., \& Murtaza, G. (2011). The Relationship between stock market volatility and macroeconomic volatility: Evidence from Pakistan. African Journal of Business Management, 6(24), 7387-7396.

Narayan, P. K., \& Sharma, S. S. (2011). New evidence on oil price and firm returns. Journal of Banking E Finance, 35(1), 3253-3262.

Nelson, D. B. (1991). Conditional heteroskedasticity in asset returns: A new approach. Econometrica, 59(2), 347-370.

Okpara, G. C. (2011). Volatility modeling and the Nigerian stock return relationship in EGARCH-inmean framework. International Journal of Current Research, 3(8), 176-185.

Oluseyi, A. S. (2015). An empirical investigation of the relationship between stock market prices volatility and macroeconomic variables' volatility in Nigeria. European Journal of Academic Essays, 2(11), 1-12.

Park, Y., Shin, J., \& Kim, T. (2010). Firm size, age, industrial networking, and growth: A case of the Korean manufacturing industry. Small Bus Econ, 35(1), 153-168.

Qayyum, A. \& Anwar, S. (2011). Impact of monetary policy on the volatility of stock market in pakistan. International Journal of Business and Social Science, 2(11), 18-24.

Rajput, N., Kakkar, R., Batra, G., \& Gupta, M. (2012). Price discovery in Indian stock market: the case of S\&P CNX Nifty Index. Investment Management and Financial Innovations, 9(3), 120-129.

Ramanathan, K., \& Gopalakrisnan, M. (2013). Volatility in Indian stock market-a study of post \& pre-recession period. International Journal of Management Research, 3(1), 133-143.

Rossetti, N., Rossetti, N., Nagano, M. S., Nagano, M. S., Meirelles, J. L. F., \& Meirelles, J. L. F. (2017). A behavioral analysis of the volatility of interbank interest rates in developed and emerging countries. Journal of Economics, Finance and Administrative Science, 22(42), 99-128.

Sagi, J. S., \& Seasholes, M. S. (2007). Firm-specific attributes and the cross-section of momentum. Journal of Financial Economics, 84(2), 389-434.

Saleem, K. (2007). Modeling time-varying volatility and asymmetry of Karachi Stock Exchange (KSE). 
International Journal of Economic Perspectives, 1(1), 1-9.

Salisu, A. A., \& Oloko, T. F. (2015). Modeling oil price-US stock nexus: A VARMA-BEKK-AGARCH approach. Energy Economics, 50(1), 1-12.

Salman, A. K., \& Yazdanfar, D. (2012). Profitability in Swedish micro firms: A quantile regression approach. International Business Research, 5(8), 94-106.

Sari, R., Hammoudeh, S., \& Soytas, U. (2010). Dynamics of oil price, precious metal prices, and exchange rate. Energy Economics, 32(2), 351-362.

Schwert, G. W. (1989). Why does stock market volatility change over time? The Journal of Finance, 44(5), 1115-1153.

Sharma, S. S., Narayan, P. K., \& Zheng, X. (2014). An analysis of firm and market volatility. Economic Systems, 38(2), 205-220.

Sim, N., \& Zhou, H. (2015). Oil prices, US stock return, and the dependence between their quantiles. Journal of Banking $\mathcal{E}$ Finance, 55(1), 1-8.

Singh, D. (2010). Causal relationship between macro-economic variables and stock market: A case study for India. Pakistan Journal of Social Sciences, 30(2), 263-274

Uhlaner, L. M., Stel, A. V., Duplat, V. R., \& Zhou, H. (2013). Disentangling the effects of organizational capabilities, innovation and firm size on sme sales growth. Small Business Economics, 41(3), 581-607.

Vickery, J. (2008). How and why do small firms manage interest rate risk? Journal of Financial Economics $87(1), 446-470$.

Walid, C., Chaker, A., Masood, O., \& Fry, J. (2011). Stock market volatility and exchange rates in emerging countries: A Markov-state switching approach. Emerging Markets Review, 12(3), 272-292.

White, M. M., \& Mala, R. (2006). Assessment of an emerging stock market: the case for Fiji's stock market. International Research Journal of Finance and Economics, 6(1), 116-132.

Zafar, N., Urooj, S. S., \& Durrani, T. T. (2008). Interest rate volatility and stock return and volatility. European Journal of Economics, Finance and Administrative Sciences, 14(1), 135-140.

Zakaria, Z., \& Shamsuddin, S. (2012). Empirical evidence on the relationship between stock market volatility and macroeconomic volatility in Malaysia. Journal of Business Studies Quarterly, 4(2), 61-71. 